\title{
Perilaku Pencarian Informasi Pemilihan Umum Tahun 2019 Pemilih Pemula di Kota Pekanbaru
}

\author{
Belli Nasution*, Rumyeni, Nita Rimayanti \\ Universitas Riau \\ Kampus Bina Widya, Jalan Hr. Soebrantas KM 12.5 Simpang Baru, Pekanbaru 28293 \\ *e-mail : belli.nasution@lecturer.unnri.ac.id
}

\begin{abstract}
The aim of this study is to determine the source of election information and the election information seeking behavior in 2019 among novice voters in Pekanbaru City. This research uses descriptive quantitative method. Data collection using a questionnaire by distributing questionnaires to research respondents as many as 377 people. Data analyzed by using the average score calculated using SPSS 2.5 . The results showed that the majority of beginner voters in Pekanbaru (66.8 percent) accessed election information through social media. The most accessed information is news about presidential and vice presidential candidates. Beginner voter information seeking behavior in Pekanbaru includes the stages of starting, chaining, browsing, differentiating, monitoring, extracting, verifying, and ending.
\end{abstract}

Keywords: Information, General Elections, Beginner Voters, Information Seeking Behavior Theory

\begin{abstract}
ABSTRAK
Penelitian ini bertujuan untuk mengetahui sumber informasi pemilu dan perilaku pencarian informasi pemilu serentak tahun 2019 di kalangan pemilih pemula di Kota Pekanbaru. Penelitian ini menggunakan metode kuantitatif deskriptif. Pengumpulan data menggunakan kuesioner dengan menyebarkan angket kepada responden penelitian sebanyak 377 orang. Analisis data menggunakan nilai skor rata-rata yang dihitung dengan menggunakan SPSS 2.5. Hasil penelitian menujukkan bahwa pemilih pemula di Kota Pekanbaru mayoritas (66,8 persen) mengakses informasi pemilu melalui media sosial. Informasi yang paling banyak diakases adalah berita yang berkaitan dengan calon presiden dan wakil presiden. Perilaku pencarian informasi pemilih pemula di Kota pekanbaru mencakup tahapan starting, chaining, browsing, differentiating, monitoring, extracting, verifying, dan ending.
\end{abstract}

Kata kunci: Informasi, Pemilu, Pemilih Pemula, Teori Perilaku Pencarian Informasi 


\section{Latar Belakang}

Bagian ini berisi deskripsi permasalahan Manusia dalam kehidupannya senantiasa membutuhkan informasi. Informasi merupakan data yang diolah sehingga memiliki nilai tambah dan memberikan manfaat bagi penggunanya (Riani 2018). Informasi merupakan sumber pengetahuan bagi seseorang. Semakin banyak informasi yang dimiliki oleh seseorang, maka orang tersebut dianggap semakin memiliki pengetahuan yang baik.

Kehidupan modern saat ini telah menjadikan informasi sebagai kebutuhan yang harus dipenuhi oleh setiap orang. Berbagai upaya dapat dilakukan agar dapat memperoleh informasi secara lengkap dan akurat. Informasi tersebar di mana-mana, mulai dari media massa seperti televisi, radio, surat kabar, media daring, media sosial maupun dari interaksi dengan orang-orang yang ada disekeliling kita.

Saat ini masyarakat disuguhkan dengan terpaan berbagai macam informasi, baik yang penting maupun tidak, yang bermanfaat maupun sia-sia, yang dapat dipercaya maupun yang mengandung berita post truth. Oleh sebab itu, sudah sementinya masyarakat memiliki kemampuan literasi informasi yang baik sehingga bisa menseleksi informasi mana layak untuk dikonsumsi dan mana yang seharusnya diabaikan.

Dalam menjelaskan pemenuhan kebutuhan informasi, Wilson (1981) dan Ellis (1989) memperkenalkan sebuah pendekatan yang dikenal dengan model perilaku pencarian informasi atau istilah lainnya model of seeking information behavior (Wilson 1999). Model ini mengasumsikan bahwa penggunaan informasi disebabkan karena adanya kebutuhan informasi. Hal inilah yang menyebkan seseorang melakukan pencarian informasi. Informasi dapat dicari melalui berbagai sumber. Apabila seseorang berhasil melakukan pencarian dan ia merasa puas, maka biasanya orang tersebut akan meneruskan informasi itu kepada orang lain. Model ini memperlihatkan bahwa perilaku pencarian informasi harus melibatkan orang lain agar terjadi pertukaran informasi. Informasi yang diperoleh tersebut digunakan baik untuk kepentingan diri sendiri maupun kepentingan orang lain (Limilia and Fuady, 2016).

Beberapa penelitian sejenis terdahulu telah melakukan pengujian terhadap model perilaku pencarian. Misalnya penelitian oleh Rohmiyati (2018), yang menemukan sebuah pola baru perilaku pencarian informasi generasi millenial dengan tahapan yang mencakup Pendorong, Searching/ Browsing/ Surfing, Seleksi, Evaluasi, Share, Repost, Evaluasi dan Respon (Rohmiyati 2018)

Penelitian lain dilakukan oleh Limilia dan Fuady (2016). Hasil penelitian menunjukkan bahwa pemilih pemula menggunakan beberapa media dalam pencarian informasi politik, seperti media konvensional, media sosial, dan media tatap muka. Terdapat beberapa topik politik yang banyak dicari oleh pemilih pemula diantaranya profil, program kerja, kepemimpinan, dan ideologi (Limilia and Fuady, 2016).

Dilihat dari hasil riset terdahulu, terbukti bahwa masyarakat memiliki perilaku pencarian informasi seperti yang dijelaskan oleh asumsi dari model pencarian informasi Wilson dan Ellis. Secara bertahap masyarakat melakukan pencarian guna memenuhi kebutuhan mereka terkait dengan informasi tertentu. Melalui proses pencarian informasi tersebut para pengguna informasi dapat memperoleh informasi melalui berbagai sumber, setelah mereka memperolehnya mereka menggunakan informasi tersebut 
sesuai dengan kebutuhan mereka dan selanjutnya mereka akan menyebarkan informasi yang ada pada mereka kepada pihak lain.

Saat ini, informasi yang paling banyak dicari, dibicarakan dan disebarkan salah satunya adalah informasi tentang pemilihan umum. Menjelang pelaksanaan pemilu pada 17 April 2019, berbagai media saling berlomba-lomba untuk memberikan informasi kepada masyarakat.

Pemilu merupakan ajang pesta demokrasi bagai masyarakat Indonesia. Pemilu yang dilaksanakan tahun ini berbeda dibandingkan dengan peridodeperiode sebelumnya. Berbeda dibandingkan dengan periode-periode sebelumnya, pada tahun 2019 pelaksanaan pemilu di Indonesia diadakan secara serentak. Penyelenggaraan pemilu legislatif dan eksekutif dilakukan pada waktu yang bersamaan. Dasar pelaksanaan pemulu serentak ini adalah Keputusan Mahkamah Konstitusi (MK) No 14/PUU-11/2013 Tentang Pemilihan Umum Serentak. Keputusan Hukum ini dihasilkan setelah dikabulkannya usulan uji materi Undang-Undang No. 42 Tahum 2008 tentang Pemilihan Presiden dan Wakil Presiden yang diajukan oleh Dr. Effendi Gazali Pakar Komunikasi Politik Universitas Indonesia bersama Koalisi Masyarakat untuk Pemilu Serentak.

Masyarakat Indonesia yang memiliki hak pilih diberikan kesempatan untuk memberikan suaranya pada pelaksanaan pemilu. Berdasarkan informasi resmi KPU, jumlah daftar pemilih tetap (DPT) pemilu tahun 2019 adalah sebanyak 192.828.520 jiwa (kompas.com, 2018. Diakses 12 Maret 2019). Selanjutnya dari jumlah tersebut terdapat 5.035 .887 pemilih yang masuk kategori pemilih pemula.

Pemilih pemula merupakan warga Negara Indonesia yang baru pertama kali menggunakan hak pilihnya dalam pemilu.
Jumlah pemilih pemula yang relatif besar disertai dengan minimnya pengalaman dan pengetahuan dari pemilih pemula, acapkali membuat mereka dijadikan sebagai sasaran kampanye. Kondisi tersebut semakin diperparah dengan banyaknya terpaan informasi hoax dan minimnya sumber informasi politik yang netral dan mendidik (Limilia and Fuady, 2016). Perludem, sebuah lembaga nirlaba yang memfokuskan aktivitasnya pada pemilu, menyebutkan beberapa karakteristik dari pemilih pemula diantaranya: pemilih kritis, social influencer, dan swing voters. KPUD Surabaya menjelaskan beberapa karakteristik pemilih pemula berdasarkan usia, di antaranya adalah: "a) belum pernah memilih atau melakukan penentuan suara di dalam TPS, b) belum memiliki pengalaman memilih, c) memiliki antusiasme yang tinggi dan kurang rasional, d) pemilih muda yang masih penuh gejolak dan semangat, e) memiliki rasa ingin tahu dan mencoba, f) berpartisispasi dalam pemilu meskipun kadang dengan berbagai latar belakang yang berbeda" (Limilia and Fuady, 2016).

Pemilih pemula merupakan swingvoter, dimana sekitar 33,9 persen masih belum menentukan partai politik yang akan dipilih dan hanya 1,5 persen saja mengetahui eksistensi dari partai baru (Soeprapto, Dn, and Suparno 2014).

Menilik dari karakteristik pemilih pemula di atas, keberadaan pemilih pemula bisa mengakibatkan dampak hasil pemilu yang positif maupun negatif. Dampak positifnya adalah keingingan yang kuat dan semangat dari mereka untuk berpartisipasi dalam pelaksanaan pemilu. Tentu saja ini mengurangi kekhawatiran kita pada aksi golput. Di sisi lain mereka merupakan konstituen yang baru akan pertama kali menggunakan hak suaranya pada pemilu, sehingga 
pengetahuan dan pengalaman mereka masih rendah, ditambah dengan karakteristik lain seperti kurang rasional, penuh gejolak dan rasa ingin tahu. Apabila mereka tidak memiliki informasi politik yang memadai, hal ini bisa berdampak pada kesalahan dalam menentukan pilihan calon legislatif dan eksekutif.

Perkembangan media massa saat ini telah begitu massif. Semua media seolah berlomba-lomba untuk menyajikan informasi terkait pelaksanaan pemilu. Keberadaan media dan keluasan informasi tersebut diharapkan dapat dimanfaatkan oleh para pemilih pemula untuk memperkaya pengetahuan politik mereka dalam menghadapi pengalaman pertama mereka untuk ikut berpartisipasi aktif dalam pelaksanaan pemilu serentak tahun 2019. Apatah lagi dengan hadirnya media daring yang begitu mudah untuk diakses oleh siapa pun, kapan pun dan di mana pun. Hal ini memberikan harapan yang besar, terkait dengan pencarian informasi politik oleh para pemilih pemula.

Ketepatan dan kecukupan informasi politik sangat dibutuhkan bagi pemilih pemula sebelum menentukan pilihan dalam bilik suara. Berdasarkan paparan latar belakang, tujuan penelitian ini adalah: 1) mengetahui sumber informasi pemilu serentak tahun 2019 di kalangan pemilih pemula di Kota Pekanbaru, dan 2) mengetahui perilaku pencarian informasi pemilu serentak tahun 2019 di kalangan pemilih pemula di Kota Pekanbaru.

\section{Kajian Pustaka}

a. Teori Perilaku Pencarian Informasi (Information Seeking Behavior)

Perilaku pencarian Informasi adalah usaha untuk menemukan berbagai informasi dengan tujuan tertentu yang diakibatkan oleh adanya kebutuhan untuk memenuhi tujuan tertentu (Rohmiyati 2018). Dalam upaya tersebut, seseorang bisa saja melakukannya dengan cara berinteraksi dengan sistem informasi manual seperti surat kabar atau perpustakaan, atau dengan sistem daring berbasis komputer, misalnya internet (Wilson 1999). Model Wilson mengasumsikan bahwa perilaku pencarian informasi berasal dari kebutuhan informasi pengguna, dan akibat dari kebutuhan tersebut menuntut tersedianya sistem informasi (seperti perpustakaan atau database), dan sumber informasi lainnya (seperti textbook, handout, dosen dan yang lainnya). Pesatnya perkembangan teknologi informasi dan komunikasi seperti yang terjadi saat ini, mengharuskan pengguna untuk lebih banyak mengakses media daring guna memenuhi kebutuhannya akan informasi.

Ellis mengembangkan teori perilaku pencarian informasi dan menyebutkan indikator perilaku pencarian informasi yang terdiri dari:

- Starting: tahapan dimana individu mulai mencari informasi, dengan cara misalnya bertanya pada seseorang yang ahli di bidang keilmuan tertentu.

- Chaining: tahapan dimana individu fokus pada hal-hal yang dianggap penting dan mengingatnya, selanjutnya menghubungkan informasi atau materi apa saja yang akan dicari kemudian.

- Browsing: merupakan kegiatan mencari informasi secara terstruktur atau semi terstruktur.

- Differentiating: perilaku memilah data mana yang akan digunakan dan mana yang tidak perlu.

- Monitoring: selalu mengikuti atau melakukan pencarian informasi yang terbaru.

- Extracting: mengambil beberapa informasi yang bermanfaat dari sumber informasi tertentu. 
- Verifying: memeriksa akurasi data yang diambil.

- Ending: merupakan tahap akhir dari proses pencarian informasi. (Riani, 2018)

Selanjutnya, Khulthau (1991) sebagaimana yang dikutip oleh Pendit (2006) mengatakan kegiatan pencarian informasi sebagai sebuah proses konstruksi yang dilalui seseorang dari tahap ketidakpastian (uncertainly) ke arah pemahaman (understanding). Terdapat 6 tahapan atau langkah yang terkandung dalam proses ini, yaitu: awalan (initiation), pemilihan (selection), penjelajahan (exploration), penyusunan (formulation), pengumpulan (collection), dan penyajian (presentation) (Rohmiyati, 2018).

Penelitian ini penulis mengambil karakteristik perilaku pencarian informasi yang disampaikan oleh Ellis (Riani, 2018) dan mengujinya pada konteks pencarian informasi politik terkait dengan pelaksanaan pemilu serentak tahun 2019 di kalangan pemilih pemula yang berdomisili di Kota Pekanbaru.

\section{b. Pemilih Pemula}

Pemilih pemula merupakan warga negara Indonesia yang berada pada kelompok usia 17 hingga 20 tahun atau mereka yang baru untuk pertama kalinya menggunakan hak pilihnya pada pemilu. Pemilih pemula merupakan konstituen swing-voter, dimana sekitar 33,9 persen masih belum menentukan pilihan partai politik dan hanya 1,5 persen saja mengetahui eksistensi dari partai baru (Soeprapto, Dn, \& Suparno 2014).

Setiajid (Emilia \& Ichwanuddin, 2015) menyebutkan karakter pemilih pemula sebagai berikut: "(1) belum pernah memilih atau menentukan suara di tempat pemungutan suara, (2) belum mempunyai pengalaman memilih, (3) mempunyai antusiasme yang tinggi, (4) kurang bersifat rasional, (5) pemilih muda yang masih penuh gejolak dan semangat, yang apabila tidak dikendalikan akan berdampak terhadap konflik-konflik sosial di dalam pemilu, (6) menjadi sasaran peserta pemilu karena jumlahnya relatif besar, (7) memiliki rasa ingin tahu, mencoba, dan berpartisispasi dalam pemilu, meskipun kadang dengan berbagai latar belakang yang berbeda" (Emilia and Ichwanuddin, 2015)

Terdapat beberapa alasan yang mendasari para pemilih pemula ikut berpartisipasi dalam pemilu. Pertama, mayoritas pemilih pemula masih memiliki kepercayaan kepada pemerintah bisa mengubah bangsa Indonesia ke arah lebih baik. Kedua, pemilih pemula berpartisipasi dikarenakan ajakan oleh orang lain. Ketiga, disebabkan iming-imingi honor yang tinggi, dan terakhir karena ikut-ikutan (Sasmita 2011). DI sisi lain, pemilih pemula tidak bersedia untuk berpartisipasi dalam pemilu disebabkan karena ketidakpercayaan kepada partai politik dan kandidat yang ada, kesalahan administrasi data pemilih, dan minimnya sosialisasi yang dilakukan KPU.

\section{Metode Penelitian}

Penelitian ini menggunakan pendekatan kuantitatif deskriptif. Penelitian deskriptif digunakan untuk mengetahui nilai variabel mandiri, baik satu variabel atau lebih tanpa bermaksud melakukan perbandingan, atau mengetahui hubungan satu variabel dengan variabel lain (Sugiyono, 2011). Penelitian ini dilakukan pada kelompok usia pemilih pemula yang berdomisili di Kota Pekanbaru. Penelitian dilaksanakan pada bulan Maret hingga April 2019.

Populasi dalam peneltian ini adalah seluruh warga Kota Pekanbaru yang masuk dalam kategori pemilih pemula berusia 17 hingga 21 tahun, atau yang baru 
pertama kali mengikuti pemilihan umum pada tahun 2019. Menurut data dari KPU Provinsi Riau, jumlahnya adalah 18.927. Berdasarkan perhitungan tabel Krejci, sampelnya menjadi 377 orang. Teknik sampling yang digunakan adalah random sampling. Teknik ini dilakukan dengan menyebarkan kuesioner baik secara online maupun langsung secara tatap muka kepada responden. Penulis menyebarkan kuesioner secara acak kepada akun pemilih pemula menggunakan aplikasi google drive dan secara langsung kepada pemilih pemula yang berdomisili di Kota Pekanbaru yang berpeluang menjadi sampel penelitian. Sebelum disebarkan kuesioner telah diuji dengan nilai reliabilitas sebesar 0,970.

\section{Hasil dan Pembahasan}

Pemilih pemula merupakan pemilih dengan rentang usia antara 17 hingga 21 tahun. Mereka merupakan pemilih potensial yang jumlahnya relatif besar. Namun demikian biasanya mereka belum memiliki kecukupan informasi dalam menentukan pilihan pada saat pelaksanaan pemilu. Mereka adalah warga negara yang baru pertama kali menggunakan hak suaranya, dengan demikian pengetahuan dan pengalaman mereka masih rendah, ditambah dengan karakteristik lain seperti kurang rasional, penuh gejolak dan rasa ingin tahu. Kondisi tersebut seringkali dimanfaatkan oleh partai politik untuk mempengaruhi suara mereka.

Guna memberikan gambaran tentang latar belakang responden peneliti menjelaskan demografi responden dari segi jenis kelamin, usia, dan pendidikan.
- Laki-laki |- Perempuan

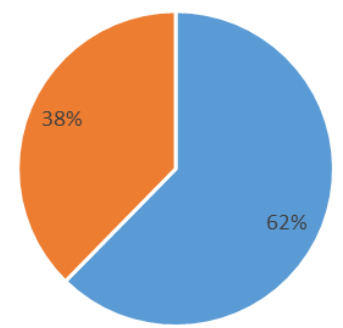

Gambar 1 Jenis kelamin responden

Gambar 1 memperlihatkan bahwa jenis kelamin responden penelitian didominasi oleh laki-laki dengan jumlah mencapai 61,7 persen, sedangkan sisanya 38,3 persen berjenis kelamin perempuan.

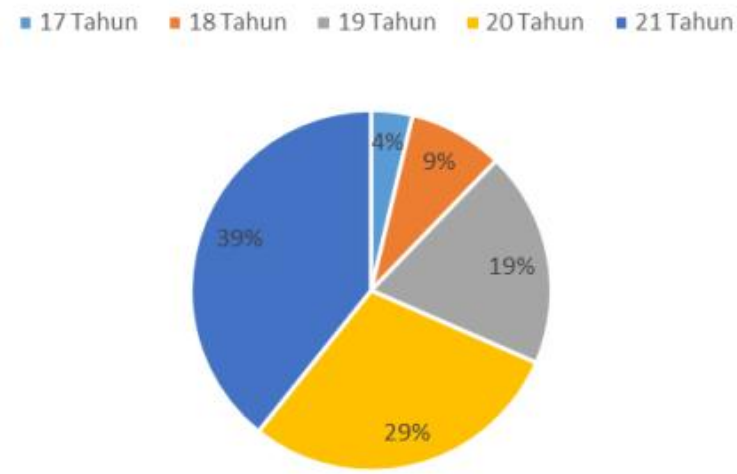

Gambar 2 Usia Responden

Dilihat dari usia, responden dalam penelitian ini mayoritas berusia 21 tahun yaitu berjumlah 38,3 persen, kemudian usia 20 tahun sebanyak 29,6 persen, yang lainnya berjumlah tidak lebih dari 20 persen, bahkan yang berusia 17 tahun hanya 3,8 persen saja. 
- Sekolah Menengah - Perguruan Tinggi

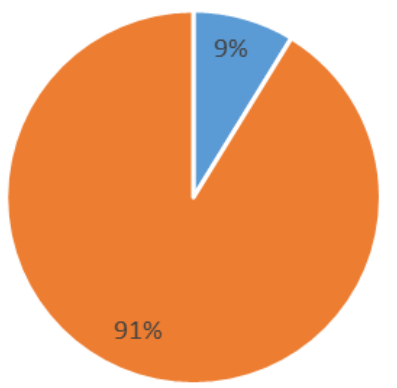

Gambar 3 Pendidikan Responden

Selanjutnya untuk kategori pendidikan, penelitian ini membaginya dalam dua kelompok, yaitu sekolah menengah dan pendidikan tinggi. Pendidikan dalam penelitian ini dimaksudkan jenjang pendidikan yang sedang ditempuh oleh responden penelitian. Rata-rata responden penelitian ini sedang menempuh jenjang pendidikan di perguruan tinggi, yaitu sebanyak 91,1 persen, dan sisanya yang menduduki jenjang sekolah menengah hanya berjumlah 8,9 persen saja. Penelitian ini memang lebih memfokuskan pada mereka yang masuk kategori pemilih pemula namun lebih banyak diambil yang memasuki akhir sebagai pemilih pemula. Alasannya adalah agar responden yang menjadi sampel penelitian sudah memiliki referensi yang cukup dalam hal informasi pemilu.

Sebelum menentukan pilihan pada saat pelaksanaan pemilu, pemilih pemula di Kota Pekanbaru telah secara aktif mencari inforasi dari berbagai sumber.

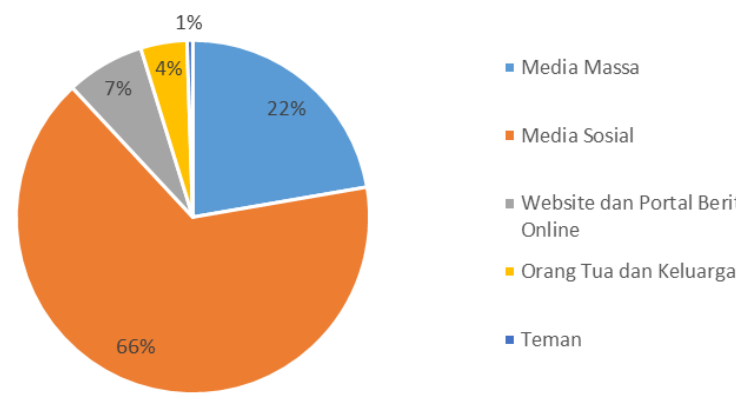

Gambar 3 Sumber informasi pemilu pemilih pemula di Kota Pekanbaru

Media memiliki peran yang besar dalam memenuhi kebutuhan informasi pemilu di kalangan pemilih pemula di Kota Pekanbaru. Dalam penelitian ini diketahui bahwa pemilih pemula mayoritas menggunakan media sosial sebagai media referensi pemilu, yaitu sebanyak 66,8 persen. Hal ini dapat dimaklumi mengingat karakteristik dari pemilih pemula adalah berusia remaja akhir atau dewasa awal yang notabene lebih menyukai penggunaan media daring dalam berbagai aktivitas mereka. Sebagaimana YPMA (Pramiyanti, Putri, and Nureni 2011) mengatakan bahwa remaja merupakan kategori digital native, yaitu generasi internet, generasi digital, atau para milenial. Generasi ini mengakses teknologi internet, dan memiliki ketrampilan dan pengetahuan yang baik tentang komputer. Meskipun demikian masih relatif banyak jumlah pemilih pemula di Kota Pekanbaru yang juga mengakses informasi pemilu dari sumber yang lain misalnya dari media massa. Jumlahnya mencapai 21 persen dari total keseluruhan responden. Mereka memperoleh informasi pemilu dari beritaberita di televisi, surat kabar dan radio. Sementara itu sumber informasi lain seperti sumber langsung dari orang disekitar mereka hanya memiliki kontribusi kecil, tidak lebih dari 5 persen.

Temuan ini sejalan dengan asumsi teori perilaku pencari informasi oleh Wilson (1999) yang menjelaskan bahwa perilaku pencarian informasi bersumber dari kebutuhan akan informasi pengguna, dan respon terhadap kebutuhan tersebut menuntut pada tersedianya sistem informasi (Wilson 1999). Perkembangan internet yang pesat seperti saat ini, mengakibatkan pengguna lebih banyak 
mengakses media daring untuk memenuhi kebutuhan informasinya.
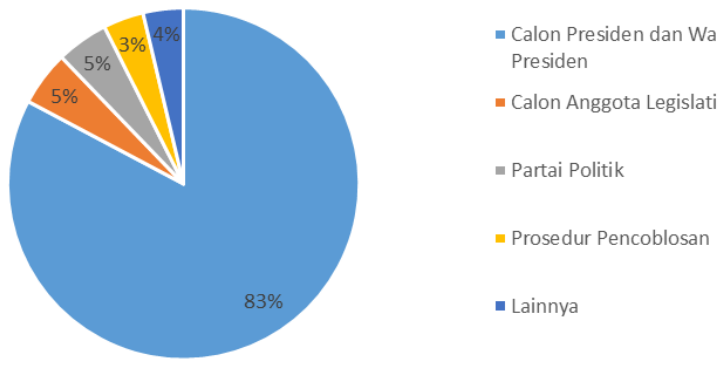

Gambar 4 Informasi Pemilu yang Paling Banyak Dicari Pemilih Pemula

Berbagai jenis informasi dicari oleh pemilih pemula di Kota Pekanbaru. Pada penelitian ini ditemukan bahwa informasi yang paling banyak dicari adalah informasi tentang calon presiden dan wakil presiden, yaitu sebanyak 84,1 persen. Hal ini menunjukkan bahwa informasi calon presiden dan wakil presiden merupakan informasi yang paling ingin diketahui oleh pemilih pemula di Kota Pekanbaru. Dari sudut pandang media, penelitian yang dilakukan oleh Pratiwi juga menunjukkan bahwa tokoh partai politik atau capres dan cawapres merupakan sumber berita yang paling banyak diberitakan di media yang diteliti (Pratiwi, 2019).

a. Perilaku Pencarian Informasi Pemilu 2019 Pemula di Kota Pekanbaru

Setelah menjabarkan tentang profil demografi responden dan sumber informasi pemilu, selanjutnya penulis akan mendeskripsikan tentang tanggapan responden terkait dengan tahapan perilaku pencarian informasi.

\section{b. Starting}

Starting merupakan tahapan dimana pemilih pemula mulai melakukan pencarian informasi, misalnya dengan bertanya pada seseorang yang dianggap memiliki pengetahuan yang baik terkait informasi politik dan pemilu. Informasi tersebut bisa juga dicari dari sumber lain seperti media massa atau referensi lainnya.

Terdapat dua pernyataan dalam indikator Starting. Jawaban responden menunjukkan rata-rata mereka setuju pada ke dua item pertanyaan tersebut.

Tabel 1 Perilaku Pencarian Informasi Pemilu Tahapan Starting

\begin{tabular}{lccccc}
\hline \multirow{2}{*}{ Starting } & \multicolumn{5}{c}{ Tanggapan Responden } \\
\cline { 2 - 6 } & STS & TS & R & S & SS \\
& $(\%)$ & $(\%)$ & $(\%)$ & $(\%)$ & $(\%)$ \\
\hline $\begin{array}{l}\text { Saya mulai mencari informasi pemilu melalui media/ } \\
\text { bertanya pada orang lain }\end{array}$ & 1,3 & 6,7 & 10,5 & 70,4 & 14,8 \\
\hline $\begin{array}{l}\text { Pencarian awal dilakukan karena belum memahami } \\
\text { pelaksanaan pemilu }\end{array}$ & 3,5 & 6,7 & 12,4 & 64,2 & 13,2 \\
\hline N: 377, Mean: 3,8621, SD: 0,69840 & & & & & \\
\hline \multicolumn{1}{c}{ Sumber: Data Olahan Peneliti, 2019} \\
\end{tabular}

Berdasarkan hasil perhitungan mean, diperoleh rata-rata skor indikator starting ialah 3,9, nilai tersebut berada pada kategori setuju. Hal ini berarti responden setuju bahwa pemilih pemula memulai pencarian informasi melalui berbagai media dan bertanya kepada orang-orang yang dianggap mengetahui tentang pelaksanaan pemilu dan aktivitas tersebut mereka lakukan karena mereka merasa belum banyak tahu tentang informasi pemilu serentak tahun 2019. 
Chaining merupakan tahapan dimana pemilih pemula mencatat hal-hal yang dianggap penting dan mengaitkan informasi atau materi apa saja yang akan dicari kemudian. Tabel 2 menjabarkan tanggapan responden tentang indikator chaining.

Tabel 2 Perilaku Pencarian Informasi Pemilu Tahapan Chaining

\begin{tabular}{|c|c|c|c|c|c|}
\hline \multirow[b]{2}{*}{ Chaining } & \multicolumn{5}{|c|}{ Tanggapan Responden } \\
\hline & $\begin{array}{l}\text { STS } \\
(\%)\end{array}$ & $\begin{array}{l}\text { TS } \\
(\%)\end{array}$ & $\begin{array}{c}\mathrm{R} \\
(\%)\end{array}$ & $\begin{array}{c}S \\
(\%)\end{array}$ & $\begin{array}{l}\text { SS } \\
(\%)\end{array}$ \\
\hline $\begin{array}{l}\text { Saya mendapatkan informasi tentang pemilu dari berbagai } \\
\text { sumber }\end{array}$ & 1,1 & 1,6 & 8,4 & 69,8 & 19,1 \\
\hline $\begin{array}{l}\text { Saya selalu mengaitkan informasi dari satu sumber dengan } \\
\text { sumber yang lain }\end{array}$ & 1,1 & 3,2 & 16,4 & 59,8 & 19,4 \\
\hline $\begin{array}{l}\text { Saya memiliki sumber informasi pemilu utama dan sumber } \\
\text { informasi lain sebagai pelengkap }\end{array}$ & 1,9 & 3,5 & 18,3 & 63,1 & 13,2 \\
\hline N: 377, Mean: 3,9333, SD: 0,65220 & & & & & \\
\hline
\end{tabular}

Sebagaimana yang terlihat pada tabel 2 , responden dalam penelitian ini rata-rata menjawab setuju pada tiga item pernyataan yang tersaji. Hal ini juga didukung oleh hasil perhitungan nilai ratarata (mean), diperoleh rata-rata skor indikator chainning ialah 3,9. Hal ini berarti responden setuju bahwa pemilih pemula mendapatkan informasi pemilu dari berbagai sumber, mereka mengaitkan informasi yang diperoleh dari satu sumber informasi dengan sumber lainnya, dan pemilih pemula selain memiliki sumber informasi yang utama, mereka juga mengakses sumber lain sebagai pelengkap.

\section{d. Browsing}

Tahapan browsing merupakan kegiatan pencarian informasi pemilu yang terstruktur atau semi terstruktur. Untuk mengetahui tanggapan responden tentang indikator atau tahapan pencarian informasi browsing, penulis menyampaikan dua pernyataan yang terangkum dalam tabel 3 .

Tahap Browsing terdapat dua item pernyataan yang diajukan kepada responden. Sebagaimana yang tersaji pada Tabel 3 terlihat bahwa mayoritas responden menjawab setuju untuk setiap pernyataan.

Tabel 3 Perilaku Pencarian Informasi Pemilu Tahapan Browsing

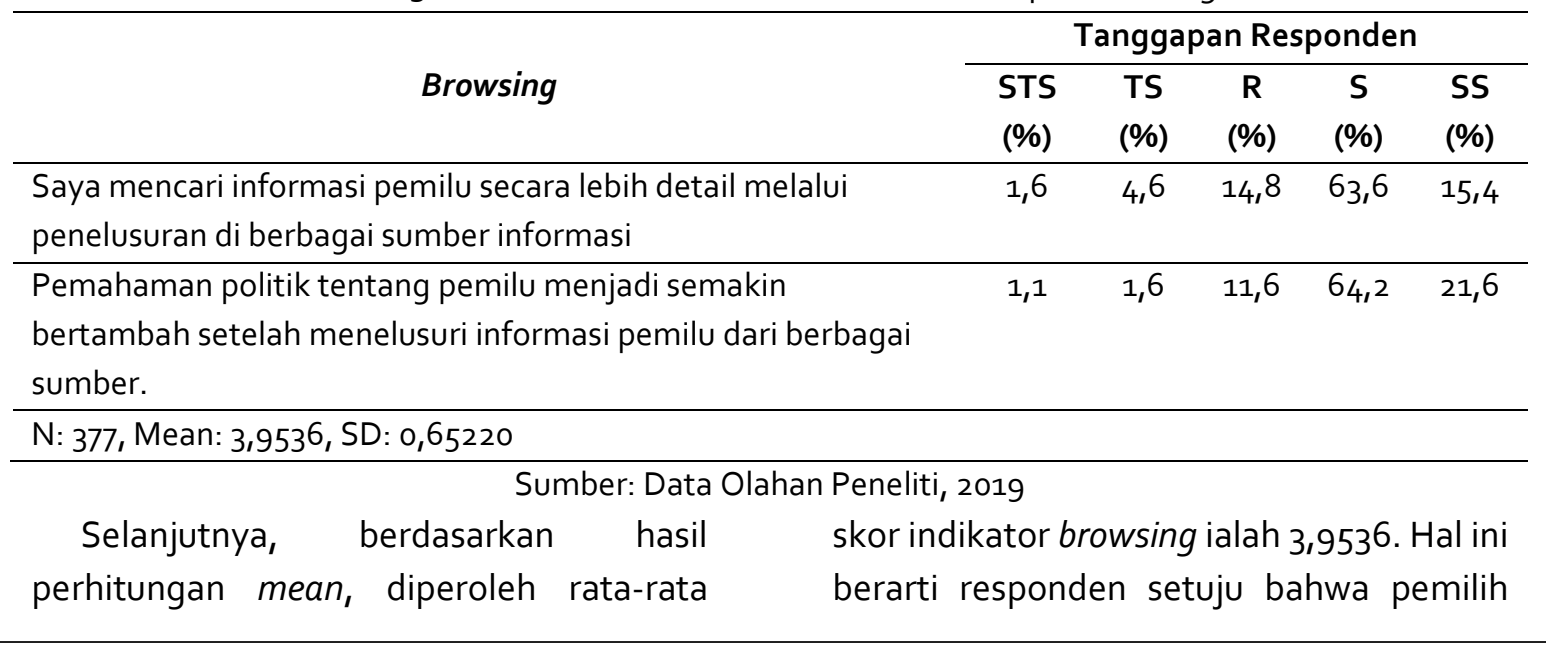


pemula mendapatkan informasi pemilu secara detail dengan melakuakn penelusuran ke berbagai sumber baik media konvensional, media sosial, portal berita maupun kepada orangorang yang kredibel. Setelah mereka melakukan penelusuran tersebut pengetahuan dan pemahaman politik mereka semakin meningkat.

Tabel 4 Perilaku Pencarian Informasi Pemilu Tahapan Differentiating

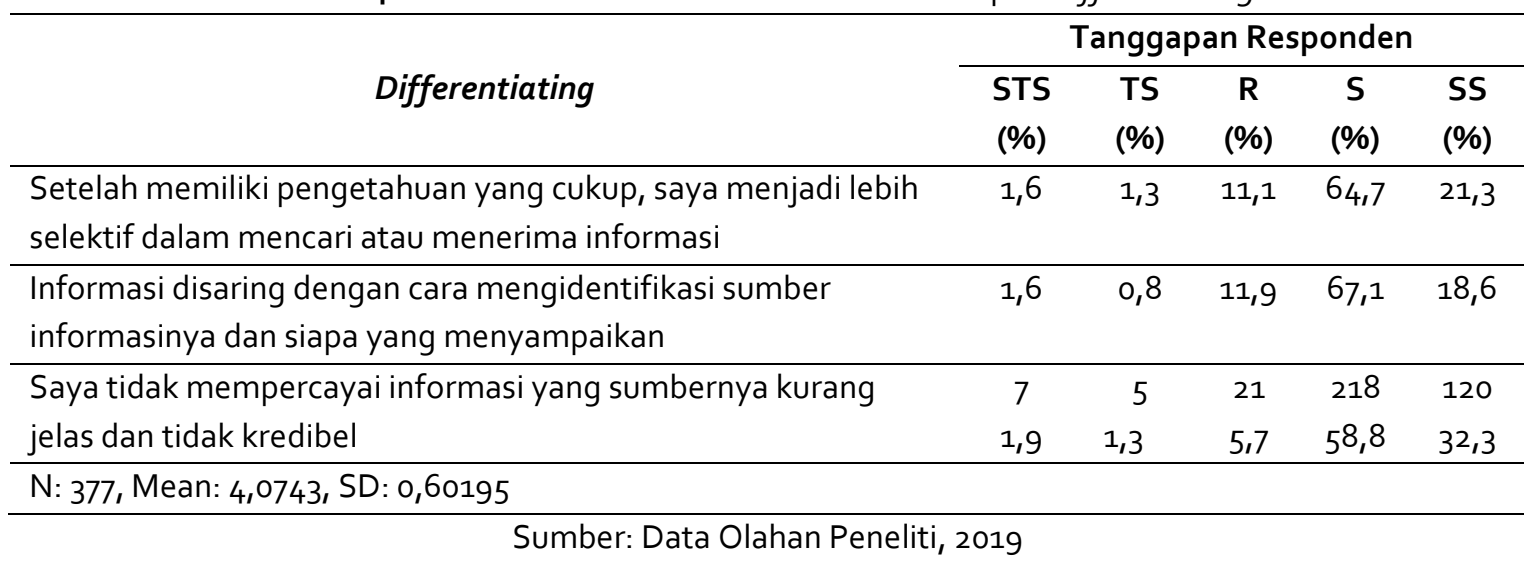

\section{e. Differentiating}

Tahapan Differenting mengacu pada pemilihan data mana yang akan digunakan oleh pemilih pemula dan mana yang tidak perlu.

Pemilih pemula melakukan penyaringan terhadap berbagai informasi yang mereka terima. Berdasarkan jawaban responden dapat diketahui bahwa mayoritas responden menjawab opsi setuju pada tiga item pernyataan yang disediakan.

Hasil perhitungan mean diperoleh ratarata skor indikator differentiating adalah 4,0743. Hal ini berarti pemilih pemula setuju bahwa mereka menjadi lebih selektif terhadap infomasi yang diterima setelah mereka memiliki pengetahuan yang cukup. Mereka menyaring informasi yang diperoleh dengan mengenali komunikatornya, dan mereka tidak mempercayai sumber informasi yang kurang kredibel.

\section{f. Monitoring}

Monitoring adalah tahapan ketika pemilih pemula selalu mengikuti atau mencari informasi yang terbaru. Tabel 5 menunjukkan bahwa mayoritas responden menjawab setuju pada dua pernyataan yang diajukan.

Berdasarkan perhitungan nilai mean, diperoleh rata-rata skor indikator monitoring adalah 3,7440. Hal ini berarti pemilih pemula setuju bahwa mereka memantau perkembangan informasi pemilu melalui berbagai media dan sumber yang dipilih dan diyakini kebenarannya. Selanjutnya, mereka mengikuti akun media sosial dan portal berita agar informasi politik dan pemilu selalu update.

Tabel 5 Perilaku Pencarian Informasi Pemilu Tahapan Monotoring

\begin{tabular}{|c|c|c|c|c|c|}
\hline \multirow[b]{2}{*}{ Monitoring } & \multicolumn{5}{|c|}{ Tanggapan Responden } \\
\hline & $\begin{array}{l}\text { STS } \\
(\%)\end{array}$ & $\begin{array}{c}\text { TS } \\
(\%)\end{array}$ & $\begin{array}{c}\mathrm{R} \\
(\%)\end{array}$ & $\begin{array}{c}S \\
(\%)\end{array}$ & $\begin{array}{l}\text { SS } \\
(\%)\end{array}$ \\
\hline $\begin{array}{l}\text { Informasi pemilu dipantau melalui sumber-sumber yang } \\
\text { dipilih dan diyakini kebenarannya }\end{array}$ & 2,4 & 2,4 & 15,4 & 66,8 & 12,9 \\
\hline
\end{tabular}




\begin{tabular}{|c|c|c|c|c|c|}
\hline $\begin{array}{l}\text { Saya mengikuti akun media sosial atau portal berita agar } \\
\text { informasi pemilu selalu update }\end{array}$ & 3 & 11,3 & 16,7 & 58,5 & 10,5 \\
\hline $\mathrm{N}: 377$, Mean: 3,7440, SD: 0,73577 & & & & & \\
\hline
\end{tabular}

\section{g. Extracting}

Tahapan Extracting merupakan tahapan ketika pemilih pemula mengambil salah satu informasi yang berguna dalam sebuah sumber informasi tertentu.
Tanggapan responden pada indikator extracting disajikan pada tabel 6.

Sebagaimana yang terlihap pada tabel 6, mayoritas rensponden memberikan jawaban setuju untuk indikator extracting.

Tabel 6: Perilaku Pencarian Informasi Pemilu Tahapan Extracting

\begin{tabular}{|c|c|c|c|c|c|}
\hline \multirow[b]{2}{*}{ Extracting } & \multicolumn{5}{|c|}{ Tanggapan Responden } \\
\hline & $\begin{array}{l}\text { STS } \\
(\%)\end{array}$ & $\begin{array}{l}\text { TS } \\
(\%)\end{array}$ & $\begin{array}{c}\mathrm{R} \\
(\%)\end{array}$ & $\begin{array}{c}S \\
(\%)\end{array}$ & $\begin{array}{l}\text { SS } \\
(\%)\end{array}$ \\
\hline $\begin{array}{l}\text { Saya hanya mengakses sumber informasi pemilu yang sesuai } \\
\text { dengan kebutuhannya }\end{array}$ & 1,9 & 4,6 & 12,1 & 69 & 12,4 \\
\hline $\begin{array}{l}\text { Saya memilih sumber informasi pemilu yang dianggap paling } \\
\text { penting }\end{array}$ & 1,3 & 3,2 & 12,7 & 71,2 & 11,6 \\
\hline
\end{tabular}

N: 377, Mean: 3,8753, SD: 0,64750

\section{Sumber: Data Olahan Peneliti, 2019}

Hasil jawaban responden juga didukung oleh hasil perhitungan nilai mean, yang diperoleh rata-rata skor indikator monitoring adalah 3, 8753. Hasil perhitungan nilai mean bermakna pemilih pemula setuju bahwa mereka hanya mengakses sumber infromasi pemilu yang relevan dengan kebutuhan mereka. Pemilih pemula yang setuju bahwa memilih sumber informasi yang paling penting dan sesuai dengan kebutuhan.

\section{h. Verifying}

Pada tahapan Verifying pemilih pemula mengecek akurasi data yang telah diambil dari berbagai sumber informasi.

Terdapat dua pertanyaan yang diajukan kepada responden untuk indikator ini. Dari kedua pertanyaan tersebut, jawaban responden didominasi oleh opsi setuju.

\section{Tabel 7: Perilaku Pencarian Informasi Pemilu Tahapan Verifying}

\begin{tabular}{|c|c|c|c|c|c|}
\hline \multirow[b]{2}{*}{ Verifying } & \multicolumn{5}{|c|}{ Tanggapan Responden } \\
\hline & $\begin{array}{l}\text { STS } \\
(\%)\end{array}$ & $\begin{array}{l}\text { TS } \\
(\%)\end{array}$ & $\begin{array}{c}\mathrm{R} \\
(\%)\end{array}$ & $\begin{array}{c}S \\
(\%)\end{array}$ & $\begin{array}{l}\text { SS } \\
(\%)\end{array}$ \\
\hline $\begin{array}{l}\text { Saya selalu mengecek kebenaran informasi dengan cara } \\
\text { dengan sumber berita yang lain }\end{array}$ & 0,8 & 2,7 & 11,3 & 69,8 & 15,4 \\
\hline $\begin{array}{l}\text { Saya hanya mempercayai sumber informasi yang faktual dan } \\
\text { tidak pernah menyebarkan hoax }\end{array}$ & 1,6 & 1,3 & 9,4 & 61,5 & 26,1 \\
\hline N: 377, Mean: 4,0318, SD: 0,60872 & & & & & \\
\hline
\end{tabular}

Tanggapan responden untuk indikator ferifying selanjutnya dimasukkan dalam analisis perhitungan skor rata-rata yang dimaksudkan untuk mengetahui secara 
pasti rata-rata dari keseluruhan jawaban responden. Diperoleh rata-rata skor indikator monitoring adalah 4,0318 . Hal ini berarti pemilih pemula setuju bahwa dalam menerima informasi mereka selalu mengecek kebenaran dari informasi tersebut. Kemudian, pemilih pemula juga setuju bahwa mereka hanya mempercayai sumber berita yang faktual dan tidak pernah menyebarkan berita bohong (hoax).

\section{i. Ending}

Tahapan Ending merupakan akhir dari proses pencarian informasi. Terdapat tiga pernyataan untuk indikator ini. Pernyataan pada indikator ending mayoritas dijawab setuju oleh responden. Tanggapan responden untuk indikator ending selanjutnya dimasukkan dalam analisis perhitungan skor rata-rata.

Tabel 7 Perilaku Pencarian Informasi Pemilu Tahapan Ending

\begin{tabular}{|c|c|c|c|c|c|}
\hline \multirow[b]{2}{*}{ Ending } & \multicolumn{5}{|c|}{ Tanggapan Responden } \\
\hline & $\begin{array}{l}\text { STS } \\
(\%)\end{array}$ & $\begin{array}{l}\text { TS } \\
(\%)\end{array}$ & $\begin{array}{l}\mathrm{R} \\
(\%)\end{array}$ & $\begin{array}{l}\text { S } \\
(\%)\end{array}$ & $\begin{array}{l}\text { SS } \\
(\%)\end{array}$ \\
\hline Saya mendiskusikan informasi pemilu dengan pihak lain & 2,7 & 2,7 & 13,7 & 65,2 & 15,6 \\
\hline $\begin{array}{l}\text { Saya menggunakan hasil diskusi tersebut sebagai dasar } \\
\text { pertimbangan dalam melakukan pemungutan suara }\end{array}$ & 3,2 & 3,5 & 12,9 & 64,4 & 15,9 \\
\hline $\begin{array}{l}\text { Aktivitas diskusi dengan pihak lain menjadikan keyakinan saya } \\
\text { dalam memberikan hak suara pada pemilu } 2019 \text { semakin tinggi }\end{array}$ & 2,7 & 4,3 & 9,4 & 63,1 & 20,5 \\
\hline N: 377, Mean: 3,9019, SD: 0,71188 & & & & & \\
\hline
\end{tabular}

Sumber: Data Olahan Peneliti, 2019

Berdasarkan hasil perhitungan, diperoleh rata-rata skor indikator monitoring adalah 3,9019. Hal ini berarti pemilih pemula setuju bahwa mereka mendiskusikan informasi pemilu yang diperoleh dengan pihak lain yang dianggap memiliki pengetahuan yang baik.

Pemilih pemula setuju bahwa mereka menggunakan hasil diskusi tersebut sebagai dasar perimbangan dalam melakukan pemungutan suara. Dan pemilih pemula juga setuju bahwa aktivitas diskusi dan sharing dengan pihak lain menjadikan keyakinan pemilih pemula dalam memberikan hak suara pada pemulu 2019 semakin tinggi.

Berdasarkan pada pengujian berbagai indikator perilaku pencarian informasi dalam penelitian ini, hasilnya menunjukkan bahwa pemilih pemula di Kota Pekanbaru memiliki antusiasme yang tinggi dalam setiap tahapan pencarian informasi. Hal ini sejalan dengan pendapat
Setiajid (Emilia and Ichwanuddin, 2015) yang menyatakan bahwa salah satu karakteristik dari pemilih pemula adalah memiliki antusiasme yang tinggi. Seterusnya Setiajid juga mengatakan bahwa pemilih pemula memiliki rasa ingin tahu yang tinggi. Hal ini terbukti dalam penelitian ini dimana sejak tahapan starting, pemilih pemula telah mulai mencari berbagai informasi pemilu dari berbagai sumber informasi seperti media sosial, portal berita, media massa, maupun bertanya langsung kepada orang-orang yang dianggap memiliki pengetahuan yang baik terkait dengan pemilu, seperti orang tua, keluarga, maupun dosen atau guru mereka. Hasil penelitian ini sejalan dengan temuan penelitian sejenis terdahulu oleh Limilia \& Fuady (2016) dimana pemilih pemula juga menggunakan beberapa media dalam pencarian informasi politik, seperti media 
konvensional, media sosial, dan media tatap muka (Limilia and Fuady, 2016).

Tidak sekedar melakukan pencarian informasi, pemilih pemula di Kota Pekanbaru juga melakukan verifikasi data dan informasi yang mereka peroleh dengan cara membandingkan dengan sumber berita yang lain. Selanjutnya mereka juga melakukan diskusi dengan orang lain sebagai akhir dari pencarian informasi guna dijadikan sebagai dasar pertimbangan dalam melakukan pemungutan suara.

Meskipun demikian, hasil penelitian ini belum bisa membuktikan tingkat partisipasi politik pemilih pemula di Kota Pekanbaru. Apakah antusiasme mereka dalam mencari informasi pemilu benarbenar membuat mereka merealisasikan tindakan pemilihan pada pelaksanaan pemilu serentak tahun 2019. Oleh sebab itu, peneliti menyarankan bagi peneliti selanjutnya yang tertarik dengan masalah ini untuk menggali keterkaitan antara perilaku pencarian informasi dengan tingkat partisipasi politik di kalangan pemilih pemula.

\section{Kesimpulan}

Terdapat dua kesimpulan yang dapat dirumuskan dalam penelitian ini yaitu: 1) Sumber informasi yang paling banyak digunakan oleh pemilih pemula di Kota Pekanbaru dalam mengakses informasi tentang pemilahan umum serentak tahun 2019 adalah media sososial seperti Facebook, Instagram, Tweeter, dan Youtube. Media sosial diakses oleh 66,8 persen dari keseluruhan responden. Selanjutnya informasi yang paling banyak dicari oleh pemilih pemula di Kota Pekanbaru adalah informasi tentang calon presiden dan wakil presiden, jumlahnya mencapai 84,1 persen. 2) Perilaku pencarian informasi yang dilakukan oleh pemilih pemula di Kota Pekanbaru meliputi pertama tahap starting dimana pemilih pemula mulai mencari informasi melalui berbagai media dan bertanya langsung kepada orang yang dianggap memiliki pengetahuan pemilu yang baik. Kedua chaining dimana pemilih pemula mulai mengaitkan satu informasi dengan informasi lainnya. Ketiga browsing dimana pemilih pemula secara detail mencari informasi pemilu melalui media daring dan media massa. Keempat differentiating, dimana pemilih pemula yang telah memiliki informasi yang cukup tentang pemilu menjadi semakin selektif dalam menerima informasi. Kelima monitoring, dimana pemilih pemula memantau informasi pemilu melalui media sosial dan akun berita agar mereka bisa selalu mendapatkan informasi yang up to date. Keenam extracting, yaitu pemilih pemula hanya mengakses sumber informasi yang relevan dan sesuai dengan kebutuhan mereka. Ketujuh verifying, dimana pemilih pemula selalu mengecek kebenaran informasi dengan membandingkannya dengan sumber yang lain, mereka menyatakan hanya mempercayai informasi yang faktual dan tidak menyebarkan hoax. Tahapan terakhir adalah ending. Pada tahapan ini pemilih pemula mendiskusikan informasi yang diperoleh dengan pihak lain. Hasil diskusi tersebut dijadikan sebagai dasar pertimbangan dalam melakukan pemungutan suara. Aktivitas diskusi ini menjadikan pemilih pemula semakin yakin untuk memberikan hak suaranya pada pemilu 2019.

\section{Referensi}

Emilia, R R, and Wawan Ichwanuddin. 2015. "Political Participation and Voting Behavior In General Election 2014." Jurnal Penelitian Politik. (12) 1: 117-35. 
Kompas.com. (2018, 12 15). News: Daftar Pemilih Tetap Hasil Perbaikan II Sebanyak 192.828.520 Orang. Retrieved 12 15, 2018, from Kompas.com: https://nasional.kompas.com/read/2 018/12/15/16471061/daftarpemilih-tetap-hasil-perbaikan-iisebanyak-192828520-orang

Limilia, Putri, and Ikhsan Fuady. Pencarian Informasi Topik Politik Di Kalangan Pemilih Pemula (Studi Kasus Pola Pencarian Infomasi Politik Pada Mahasiswa Fikom Unpad ). http://kpu.go.id/dmdocuments/mod ul_1d.pdf.

Pramiyanti, Alila, Idola Perdini Putri, and Reni Nureni. 2011. "Motif Remaja dalam Menggunakan Media Baru ( Studi Pada Remaja Di Daerah SubUrban Kota Bandung )". KomuniTi. 6(2): $95-103$

Pratiwi, Ratri Ayu. 2019. "Perbandingan Isi Berita Kampanye Presiden Dan Wakil Presiden Masa Bhakti 2014-
2019 Di Indonesia." Jurnal Ilmu Komunikasi. 13 (1): 11-28.

Riani, Nur. 2018. "Model Perilaku Pencarian Informasi Guna Memenuhi Kebutuhan Informasi (Studi Literatur)." Publication Library and Information Science 1(2): 14 .

Rohmiyati, Yuli. 2018. "Model Perilaku Pencarian Informasi Generasi Milenial." Jurnal Publis. 2(4): 387-92.

Sasmita, Siska. 2011. "Peran Informasi Politik Terhadap Partisipasi Pemilih Pemula Dalam Pemilu/Pemilukada." Jurnal Ilmiah Administrasi Publik dan Pembangunan. 2(1): 217-24.

Soeprapto, Adi, Susilasti Dn, and Agus Suparno. 2014. "Komunikasi Dalam Proses Pendidikan Politik Pemilih Pemula Dalam Pemilihan Umum 2014 Di DIY." Jurnal Ilmu Komunikasi. 12 (1): 39-54.

Wilson. 1999. "Models in Information Behaviour Research". Journal of Documentation. 55 (3): 249 - 270. 